CZASOPISMO INŻYNIERII LA¿DOWEJ, ŚRODOWISKA I ARCHITEKTURY JOURNAL OF CIVIL ENGINEERING, ENVIRONMENT AND ARCHITECTURE

JCEEA, t. XXXIII, z. 63 (4/16), październik-grudzień 2016, s. 33-42

Przemysław BRZYSKI ${ }^{1}$

Stanisław FIC ${ }^{2}$

\title{
KONDENSACJA W PRZEGRODZIE ŚCIENNEJ Z KOMPOZYTU WAPIENNO-KONOPNEGO - OCENA MOŻLIWOŚCI WYSTĄPIENIA
}

\begin{abstract}
Obecność składników organicznych w materiałach budowlanych, decyduje o ich wrażliwości na wilgoć, a dłuższej perspektywie na ich korozję biologiczną, jeśli nie zostaną odpowiednio zabezpieczone przed czynnikami atmosferycznymi. Przegrody powinno się projektować zwracając uwagę na ryzyko wystąpienia powierzchniowej oraz międzywarstwowej kondensacji pary wodnej. W artykule przedstawiono analizę przegrody ściennej, wykonanej z kompozytu wapiennokonopnego. Założono grubość ściany $40 \mathrm{~cm}$ oraz po $2 \mathrm{~cm}$ tynku po obu stronach. Kompozyt składa się z modyfikowanego spoiwa wapiennego oraz paździerzy konopnych pozyskanych z konopi przemysłowych. Parametry materiału, potrzebne do analizy (współczynnik przewodności cieplnej oraz paroprzepuszczalność) wyznaczono doświadczalnie w badaniach własnych. W części analitycznej artykułu przedstawiono obliczenia temperatury powierzchni koniecznej do uniknięcia krytycznej wilgotności powierzchni wewnętrznej ściany oraz określono możliwość wystąpienia kondensacji międzywarstwowej w analizowanej ścianie. Obliczenia wykonano zgodnie z normą PN-EN 13788. Przyjęto warunki brzegowe dla lokalizacji Lublin. Miesiącem krytycznym, w którym przegroda jest najbardziej narażona na kondensację jest styczeń. Z uwagi na dobre parametry termoizolacyjne przegrody, jej budowę ryzyko rozwoju pleśni na wewnętrznej powierzchni ściany nie występuje. Kondensacja wewnętrzna występuje w przegrodzie w okresie grudzień - luty. Natomiast już w marcu zgromadzony kondensat ulega całkowitemu odparowaniu. Przegroda odpowiedniej grubości, wykonana z kompozytu wapiennokonopnego, z uwagi na swoją wysoką paroprzepuszczalność oraz niskie przewodnictwo cieplne nie jest narażona na długotrwałe i niszczące oddziaływanie skraplającej się wewnątrz pary wodnej.
\end{abstract}

Słowa kluczowe: paroprzepuszczalność, przewodnictwo cieplne, wypełniacze organiczne, wapno, ściana zewnętrzna

${ }^{1}$ Autor do korespondencji / corresponding author: Przemysław Brzyski, Politechnika Lubelska, Katedra Budownictwa Ogólnego, ul. Nadbystrzycka 40, 20-618 Lublin; tel. 815384448; p.brzyski@pollub.pl

2 Stanisław Fic, Politechnika Lubelska, Katedra Budownictwa Ogólnego, ul. Nadbystrzycka 40, 20-618 Lublin; tel. 815384443; s.fic@ pollub.pl 


\section{Wstęp}

Zrównoważone budownictwo związane jest ściśle z ograniczeniem zużycia energii $\mathrm{w}$ tym sektorze gospodarki jakim jest budownictwo. Jednym z możliwych sposobów jest stosowanie materiałów pochodzenia roślinnego w produkcji materiałów budowlanych. Do grupy materiałów pochodzenia naturalnego można zaliczyć: słomę zbożową [1], paździerze lniane [2], sizal [3], które w czasie swego wzrostu pochłaniają dwutlenek węgla, a ich wykorzystanie w budownictwie zwykle nie jest energochłonne. W przeciągu ostatnich lat szeroko zaczęto wykorzystywać paździerze konopne w produkcji materiału budowlanego, pełniącego funkcję wypełnienia ścian szkieletowych [4,5]. Obecność składników organicznych w materiałach budowlanych, decyduje o ich wrażliwości na wilgoć, a w dłuższej perspektywie na ich korozję biologiczną, jeśli nie zostaną odpowiednio zabezpieczone przed czynnikami atmosferycznymi.

$\mathrm{W}$ pracy przedstawiono analizę przegrody ściennej budynku mieszkalnego, wykonanej z kompozytu wapienno-konopnego, obustronnie otynkowanej. Obliczono temperaturę powierzchni koniecznej do uniknięcia krytycznej wilgotności powierzchni wewnętrznej ściany oraz określono możliwość wystąpienia kondensacji międzywarstwowej w analizowanej ścianie zewnętrznej.

\section{Materiały wykorzystane $w$ analizie}

W analizie wykorzystano własne badania kompozytu wapienno-konopnego. Składał się on ze spoiwa (wapno hydratyzowane (70\% wagowo) z dodatkiem pucolany $(15 \%)$ i cementu portlandzkiego (15\%)) oraz paździerzy konopnych, pochodzących z odmiany Białobrzeskie. Oprócz kompozytu, warstwami przegrody były tynki: wapienny - od zewnątrz, gliniany - od wewnątrz. Konstrukcję ściany stanowi szkielet drewniany - słupy 50x100mm rozstawione co $500 \mathrm{~mm}$, usytuowane centralnie względem grubości ściany. W obliczeniach wilgotnościowych pominięto wpływ drewnianych elementów konstrukcji na analizowane parametry. Na rysunku 1 przedstawiono schemat analizowanej przegrody, natomiast na rysunku 2 rzeczywisty model ściany.

Parametry kompozytu wapienno-konopnego takie jak współczynnik przewodności cieplnej, paroprzepuszczalność określono doświadczalnie, natomiast parametry tynków przyjęto na podstawie obowiązujących norm [6] oraz katalogu producenta [7]. 


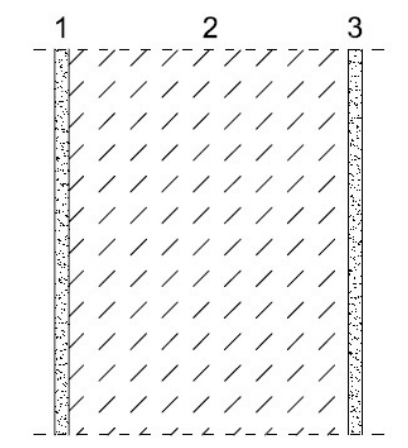

1. Tynk wapienny $20 \mathrm{~mm}$

2. Kompozyt wapienno-konopny $400 \mathrm{~mm}$

3. Tynk gliniany $20 \mathrm{~mm}$

Rys. 1. Schemat analizowanej przegrody ściennej (zewnętrznej)

Fig. 1. Scheme of analyzed external wall

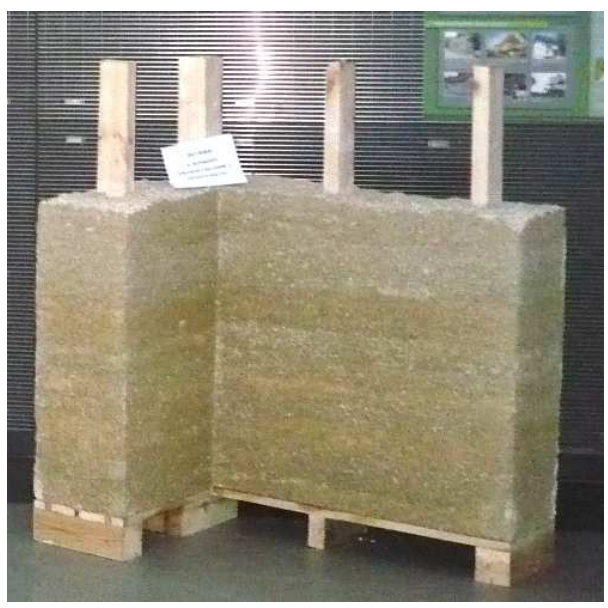

Rys. 2. Model ściany z kompozytu wapiennokonopnego (archiwum autorów)

Fig. 2. Hemp-lime wall model

\section{Wyznaczenie parametrów kompozytu wapienno-konopnego}

\subsection{Współczynnik przewodności cieplnej}

Badanie współczynnika przewodności cieplnej $\lambda$ kompozytu wykonano w oparciu o PN ISO 8302:1999 na próbkach o wymiarach 300x300x50 mm, po 28 dniach dojrzewania, przy pomocy aparatu płytowego Bocka - Fox 314. Przed umieszczeniem próbek $\mathrm{w}$ urządzeniu zostały one wysuszone do stałej masy w temperaturze $60^{\circ} \mathrm{C}$.

Wynikiem testu był średni współczynnik przewodności cieplnej materiału z sześciu pomiarów.

\subsection{Paroprzepuszczalność}

Pomiar współczynnika paroprzepuszczaloności wykonano na podstawie PNEN 12086:2013 w warunkach izotermicznych, umieszczając badaną próbkę między dwoma różnymi środowiskami, różniącymi się wilgotnością względną otaczającego powietrza. Jednym $\mathrm{z}$ nich było powietrze w eksykatorze nad roztworem soli $\left(\mathrm{K}_{2} \mathrm{CO}_{3}\right)$ zapewniającej określoną wilgotność względną (ok. 43\%). Drugim środowiskiem było powietrzne wewnątrz naczynia, w którym znajdował się żel krzemionkowy, który pozwolił uzyskać wilgotność względną 0\%. Naczynie przekryte zostało badaną próbką i obwodowo uszczelnione. Poprzez ważenie naczynia w określonych odstępach czasu ustalono przyrost masy substancji higroskopijnej. Przedstawiona metodyka badania jest opisana także przez [8]. Wyznaczając współczynnik paroprzepuszczalności $\delta$ oparto się na prawie Ficka, wg wzorów: 


$$
\begin{aligned}
& \delta=g_{\vartheta} \cdot \frac{e}{\Delta P_{\vartheta}}[\mathrm{kg} /(\mathrm{m} \cdot \mathrm{s} \cdot \mathrm{Pa})] \\
& g_{\vartheta}=\frac{\Delta m}{A \cdot \Delta T}\left[\mathrm{~kg} /\left(\mathrm{m}^{2} \cdot \mathrm{s}\right)\right]
\end{aligned}
$$

gdzie: e - grubość próbki $[\mathrm{m}] ; \mathrm{g}_{9}$ - gęstość strumienia wilgoci $\left[\mathrm{kg} /\left(\mathrm{m}^{2} \cdot \mathrm{s}\right)\right]$; $\Delta \mathrm{P}_{\vartheta}$ - gradient ciśnienia pary wodnej $[\mathrm{Pa}] ; \mathrm{A}$ - pole powierzchni próbki $\left[\mathrm{m}^{2}\right]$; $\Delta \mathrm{T}$ - zmiana temperatury $\left[{ }^{\circ} \mathrm{C}\right] ; \Delta \mathrm{m}-$ zmiana masy $[\mathrm{kg}]$.

Na podstawie współczynnika $\delta$ określono współczynnik oporu dyfuzyjnego $\mu$, co pozwoliło ustalić, ile razy opór stawiany przez dany materiał przepływowi pary wodnej jest większy od oporu powietrza, co wyrażono bezwymiarową zależnością:

$$
\mu=\frac{\delta_{0}}{\delta}
$$

gdzie: $\delta_{0^{-}}$opór powietrza, równy $2 \cdot 10^{-10} \mathrm{~kg} /(\mathrm{m} \cdot \mathrm{s} \cdot \mathrm{Pa})$

$\mathrm{W}$ tabeli 1 zestawiono wyznaczone (uśrednione) lub pobrane $\mathrm{z}$ literatury parametry materiałów wykorzystanych w analizowanej przegrodzie.

Tabela 1. Parametry materiałów wchodzących w skład analizowanej przegrody

Table 1 . The parameters of materials included in the analyzed partition

\begin{tabular}{|l|c|c|c|}
\hline \multicolumn{1}{|c|}{ Material } & $\begin{array}{c}\text { Współczynnik } \\
\text { przewodności } \\
\text { cieplnej }\end{array}$ & $\begin{array}{c}\text { Współczynnik paro- } \\
\text { przepuszczalności }\end{array}$ & $\begin{array}{c}\text { Współczynnik } \\
\text { oporu dyfuzyjnego }\end{array}$ \\
\hline & {$[\mathrm{W} / \mathrm{mK}]$} & {$[\mathrm{kg} /(\mathrm{m} \cdot \mathrm{s} \cdot \mathrm{Pa})]$} & {$[-]$} \\
\hline Kompozyt & 0,083 & $3.64 \times 10^{-11}$ & 5,5 \\
\hline Tynk wapienny & 0,80 & $2 \times 10^{-11}$ & 10 \\
\hline Tynk gliniany & 0,91 & $2.5 \times 10^{-11}$ & 8 \\
\hline
\end{tabular}

\section{Obliczenie temperatury powierzchni koniecznej do uniknięcia krytycznej wilgotności powierzchni}

Przegrody zewnętrzne powinny być zaprojektowane z uwzględnieniem ryzyka wystąpienia powierzchniowej kondensacji pary wodnej. Na wewnętrznej powierzchni nieprzezroczystej przegrody zewnętrznej nie dopuszcza się wystąpienia kondensacji pary wodnej umożliwiającej rozwój grzybów pleśniowych. Opierając się na normie PN-EN ISO 13788 [9] warunek ten sprawdzono poprzez obliczenie współczynnika temperaturowego $f_{\text {Rsi. Ściana zewnętrzna, wg zaleceń }}$ 
w/w normy powinna charakteryzować się współczynnikiem temperaturowym nie większym niż jego wartość krytyczna $\mathrm{f}_{\text {Rsi.kryt. Współczynnik temperaturowy }}$ obliczono według wzorów:

$$
\begin{aligned}
& f_{R s i},_{\text {min }}=\frac{\theta_{s i, \text { min }}-\theta_{e}}{\theta_{i}-\theta_{e}} \\
& f_{R s i}=1-\frac{R_{s i, \text { min }}}{R_{T, \text { min }}}
\end{aligned}
$$

gdzie: $\theta_{\text {si,min }}$ - temperatura powierzchni wewnętrznej $\left[{ }^{\circ} \mathrm{C}\right] ; \theta_{\mathrm{i}}-$ temperatura powietrza wewnętrznego $\left[{ }^{\circ} \mathrm{C}\right] ; \theta_{\mathrm{e}}-$ temperatura powietrza zewnętrznego [ ${ }^{\circ} \mathrm{C}$; $\mathrm{R}_{\mathrm{si} \text {,min }}$ - opór przejmowania ciepła na wewnętrznej powierzchni przegrody $\left(0,25 \mathrm{~m}^{2} \cdot \mathrm{K} / \mathrm{W}\right) ; \mathrm{R}_{\mathrm{T}, \min }$ - najniższy opór cieplny sekcji wydzielonej z komponentu budowlanego $\left[\mathrm{m}^{2} \cdot \mathrm{K} / \mathrm{W}\right]$

Aby możliwe było sprawdzenie warunku $f_{R s i}>f_{R s i, k r y t}$ konieczne jest wyznaczenie ciśnienia pary wodnej nasyconej $p_{\text {sat }}$, ciśnienia rzeczywistego pary wodnej na powierzchni zewnętrznej $p_{e}$ i wewnętrznej $p_{i}$ przegrody, oraz obliczenie minimalnej dopuszczalnej temperatury $\theta_{\text {si,min }}$ będącą najniższą temperaturą powierzchni wewnętrznej, poniżej której zaczyna rozwijać się pleśń. Aby uniknąć rozwoju pleśni, wilgotność względna na powierzchni nie powinna przekraczać wartości 0,8 . Wartości te obliczono wg wzorów:

$$
\begin{aligned}
& p_{s a t}=610,5 \cdot e^{\frac{17,26 \cdot \theta_{e}}{237,5+\theta_{e}}} \text { dla } \theta_{\mathrm{e}} \geq 0^{\circ} \mathrm{C} \\
& p_{s a t}=610,5 \cdot e^{\frac{21,875 \cdot \theta_{e}}{265,5+\theta_{e}}} \text { dla } \theta_{\mathrm{e}}<0^{\circ} \mathrm{C} \\
& p_{e}=\varphi_{e} \cdot p_{\text {sat }} \\
& p_{i}=p_{e}+1,1 \cdot \Delta p
\end{aligned}
$$

gdzie: $\Delta \mathrm{p}$ - nadwyżka ciśnienia zgodnie z oczekiwanym sposobem eksploatacji budynku $[\mathrm{Pa}]$;

$$
p_{s t a\left(\theta_{s i, \min }\right)}=\frac{p_{i}}{0,8}
$$




$$
\theta_{s i, \min }=\frac{237,5 \ln \left(\frac{p_{\text {sat }}}{610,5}\right)}{17,269-\ln \left(\frac{p_{\text {sat }}}{610,5}\right)} \mathrm{dla} \mathrm{p}_{\text {sat }(\theta \mathrm{si}, \min )} \geq 610,5 \mathrm{~Pa}
$$

Analizy stanu wilgotności ściany w budynku mieszkalnym całorocznym dokonano przyjmując jako lokalizację miasto Lublin. W tabeli 2 przedstawiono dane wyjściowe oraz wyniki obliczeń.

Tabela 2. Warunki brzegowe do obliczeń oraz wyniki obliczeń

Table 2 . The boundary conditions for calculation and the results of calculation

\begin{tabular}{|c|c|c|c|c|c|c|c|c|c|c|}
\hline M-c & $\begin{array}{c}\boldsymbol{\theta e} \\
{\left[{ }^{\circ} \mathbf{C}\right]}\end{array}$ & $\begin{array}{c}\varphi \mathrm{e} \\
{[\%]}\end{array}$ & $\begin{array}{c}\varphi \mathrm{i} \\
{[\%]}\end{array}$ & $\begin{array}{c}\mathbf{p e} \\
{[\mathrm{Pa}]}\end{array}$ & $\begin{array}{c}\Delta \mathbf{p} \\
{[\mathrm{Pa}]}\end{array}$ & $\begin{array}{c}\mathbf{p i}_{\mathrm{i}} \\
{[\mathrm{Pa}]}\end{array}$ & 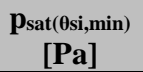 & $\begin{array}{c}\boldsymbol{\theta}_{\text {si,min }} \\
{\left[{ }^{\circ} \mathbf{C}\right]}\end{array}$ & fRsi,min & fRsi \\
\hline I & $-2,6$ & 87 & 61 & 428 & 915 & 1435 & 1794 & 15,8 & 0,814 & \multirow{12}{*}{0,95} \\
\hline II & $-1,9$ & 86 & 61 & 449 & 887 & 1424 & 1780 & 15,7 & 0,803 & \\
\hline III & 3,2 & 81 & 59 & 624 & 680 & 1373 & 1716 & 15,1 & 0,709 & \\
\hline IV & 9,2 & 73 & 57 & 844 & 437 & 1326 & 1657 & 14,6 & 0,496 & \\
\hline $\mathrm{V}$ & 14,4 & 73 & 62 & 1205 & 227 & 1454 & 1818 & 16,0 & 0,287 & \\
\hline VI & 16,2 & 78 & 68 & 1430 & 154 & 1599 & 1999 & 17,5 & 0,343 & \\
\hline VII & 16,9 & 78 & 70 & 1495 & 126 & 1633 & 2041 & 17,8 & 0,301 & \\
\hline VIII & 16,9 & 77 & 70 & 1487 & 126 & 1625 & 2032 & 17,8 & 0,277 & \\
\hline IX & 12,8 & 83 & 66 & 1221 & 292 & 1542 & 1927 & 16,9 & 0,572 & \\
\hline$X$ & 8,5 & 84 & 62 & 928 & 466 & 1440 & 1800 & 15,8 & 0,639 & \\
\hline XI & 1,3 & 89 & 61 & 598 & 757 & 1431 & 1789 & 15,8 & 0,773 & \\
\hline XII & $-2,1$ & 88 & 62 & 453 & 895 & 1438 & 1797 & 15,8 & 0,811 & \\
\hline
\end{tabular}

Miesiącem krytycznym ze względu na poziom $\mathrm{f}_{\text {Rsi }}$ jest styczeń. Obliczony współczynnik temperaturowy dla miesiąca stycznia wyniósł 0,814 , nieco mniejszą wartość współczynnika uzyskano dla grudnia 0,811 . W tym przypadku współczynnik temperaturowy $\mathrm{f}_{\mathrm{Rsi}}$ wyniósł 0,950 . Jest on większy od współczynnika krytycznego, więc warunki dla rozwoju pleśni na powierzchni wewnętrznej ściany nie występują przez cały rok.

\section{Określenie możliwości wystąpienia kondensacji międzywarstwowej}

Opierając się na normie PN-EN ISO 13788 dla każdego miesiąca obliczono temperatury na styku warstw przegrody, ciśnienie pary nasyconej i rozkład pary $\mathrm{w}$ przegrodzie. Ścianę podzielono na szereg równoległych, jednorodnych warstw, dla których określono się opory cieplne $\mathrm{R}$ oraz równoważne dyfuzyjnie warstwy powietrza $s_{d}$ wg wzoru: 


$$
s_{d}=\mu \cdot d
$$

gdzie: $\mu$ - współczynnik oporu dyfuzyjnego [-]; d- grubość warstwy materiału [m].

Zgodnie z normą [9], warstwy o znacznym oporze cieplnym $\left(\mathrm{R}>0,25 \mathrm{~m}^{2} \mathrm{~K} / \mathrm{W}\right)$ podzielono na pewną liczbę warstw o takim samym oporze cieplnym, nieprzekraczającym $0,25 \mathrm{~m}^{2} \mathrm{~K} / \mathrm{W}$.

Następnie obliczono narastający opór cieplny i grubość warstwy nieruchomego powietrza o takim samym oporze dyfuzyjnym od strony zewnętrznej do każdej powierzchni stykowej $n$, wg równań:

$$
\begin{aligned}
& R_{T}^{\prime}=R_{s i}+\sum_{j=1}^{N} R_{j}+R_{s e} \\
& s_{d, T}^{\prime}=\sum_{j=1}^{N} s_{d, j}
\end{aligned}
$$
nia:

Temperaturę na każdej powierzchni styku materiałów obliczono z równa-

$$
\theta_{n}=\theta_{e}+\frac{R_{n}^{\prime}}{R_{T}^{\prime}} \cdot\left(\theta_{i}-\theta_{e}\right)
$$

Strumień kondensacji jest różnicą między ilością wilgoci przenoszonej do powierzchni stykowej a ilością wilgoci przenoszonej od powierzchni stykowej, na której występuje kondensacja pary wodnej:

$$
g_{c}=\delta_{0} \cdot\left(\frac{p_{i}-p_{c}}{s_{d, T}^{\prime}-s_{d, c}^{\prime}}-\frac{p_{c}-p_{e}}{s_{d, c}^{\prime}}\right)
$$

$\mathrm{Na}$ rysunku 3 pokazano rozkład temperatury oraz ciśnienia pary wodnej w dwóch przegrodach w przykładowym miesiącu - styczniu. Kondensacja zachodzi wewnątrz warstwy kompozytu jedynie pomiędzy 21 a 22 warstwą stykową wytworzonych warstw obliczeniowych (styk kompozytu wapiennokonopnego z tynkiem zewnętrznym), czyli bliżej powierzchni zewnętrznej $\mathrm{w}$ przegrodzie. Temperatura ujemna utrzymuje się w obliczeniowych warstwach stykowych 19-21 (czyli w rzeczywistości w obszarze $60 \mathrm{~mm}$ grubości kompozytu od strony zewnętrznej) oraz $\mathrm{w}$ warstwie stykowej nr 22, czyli w obszarze tynku zewnętrznego. Na rysunku 4 pokazano wartości strumienia kondensacji oraz ilość zakumulowanego kondensatu w poszczególnych miesiącach. Najwyższy sumaryczny strumień kondensacji $\mathrm{g}_{\mathrm{c}}$ występuje $\mathrm{w}$ miesiącu grudniu i jest równy $0,0157 \mathrm{~kg} / \mathrm{m}^{2}$, natomiast maksymalna ilość kondensatu pary wodnej 
przypada na styczeń, w ilości $0,0259 \mathrm{~kg} / \mathrm{m}^{2}$. Kondensacja występuje w miesiącach grudzień-marzec.

Począwszy od miesiąca kwietnia skroplony kondensat ulega całkowitemu odparowaniu na skutek wzrostu temperatury zewnątrz rozpatrywanej przegrody.

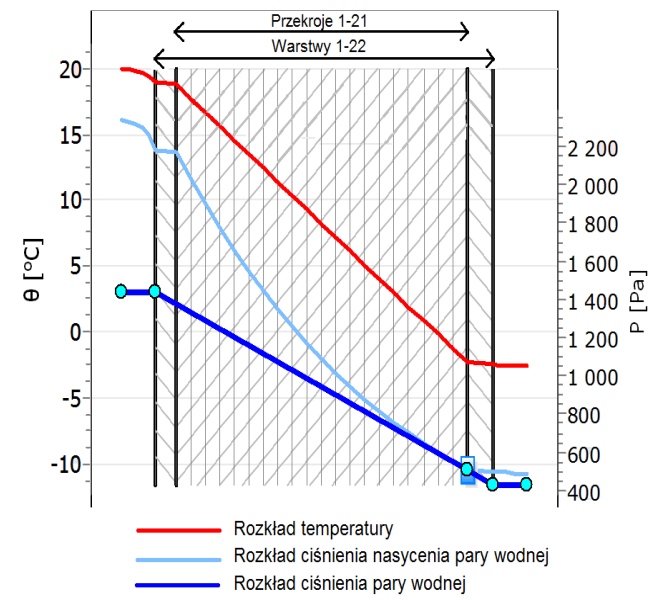

Rys. 3. Rozkład ciśnienia pary wodnej w analizowanej przegrodzie w miesiącu styczniu

Fig. 3. Distribution of water vapor pressure in analyzed partition in January

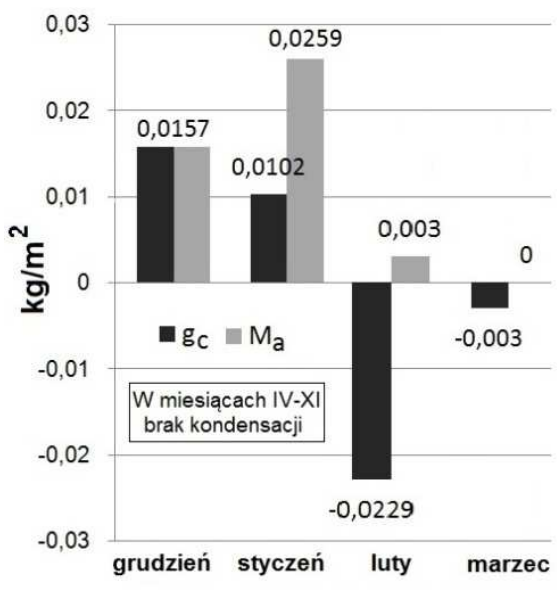

Rys. 4. Strumień kondensacji $\left(\mathrm{g}_{\mathrm{c}}\right)$ i zakumulowana wilgoć $\left(\mathrm{M}_{\mathrm{a}}\right)$ w analizowanej ścianie

Fig. 4. Streams of condensation $\left(\mathrm{g}_{\mathrm{c}}\right)$ and accumulated moisture $\left(\mathrm{M}_{\mathrm{a}}\right)$ in analyzed wall

\section{Podsumowanie}

Kompozyt wapienno-konopny z uwagi na swoje dobre parametry termoizolacyjne jest w małym zakresie objęty strefą ujemnych temperatur oraz podwyższonej wilgotności. Za sprawą niskiego współczynnika oporu dyfuzyjnego, niebezpieczeństwa związane wzrostem wilgotności w wyniku kondensacji międzywarstwowej są niewielkie. Kondensacja w przegrodzie występuje, jednak w miesiącach wiosennych kondensat ulega całkowitemu odparowaniu. Ściana zewnętrzna wykonana $\mathrm{z}$ naturalnych materiałów, takich jak kompozyt wapiennokonopny może być wolna od ryzyka rozwoju pleśni i negatywnych skutków w wyniku kondensacji, która występuje w przegrodzie w małym stopniu. Przeprowadzone badania własne mogą być pomocne w praktycznych zastosowaniach w przypadku wykonywania przegród ściennych zewnętrznych na bazie kompozytu wapienno-konopnego. 
Podziękowania: Badania zostały sfinansowane $w$ ramach działalności statutowej S/14/2016.

\section{Literatura}

[1] Minke G., Mahlke F.: Building with Straw, Birkhäuser Architecture, Germany 2005.

[2] Fic S., Brzyski P.: Badanie kompozytu opartego na lekkich wypełniaczach (len i perlit) do zastosowań w budownictwie jako materiał ścienny, Przegląd Budowlany, vol.2, 2015.

[3] Izquierdo I.S., Ramalho M.A.: Elements of structural masonry reinforced with sisal fibers, Journal of Civil Engineering and Architecture, vol.7, 2013.

[4] Barnat-Hunek D., Smarzewski P., Fic S.: Mechanical and thermal properties of hemp-lime composites, Composites Theory and Practice, vol. 15/1, 2015, pp. 21-27.

[5] Fic S., Barnat-Hunek D., Smarzewski P., Zadrożniak B.: Development of technology for the construction of clean and energy efficient house with composite filling timber frame, Biała Podlaska. Vol.1, 2015.

[6] PN-EN ISO 10456: Materiały i wyroby budowlane. Właściwości cieplnowilgotnościowe.

[7] www.tierrafino.pl, dostęp 15-05-2015.

[8] Walker R., Pavía S.: Moisture transfer and thermal properties of hemp-lime concretes, Construction and Building Materials, vol. 64, 2014; pp. 270-276.

[9] PN-EN ISO 13788:2003: Cieplno-wilgotnościowe właściwości komponentów budowlanych i elementów budynku.

\section{EVALUATION OF THE POSSIBILITY OF CONDENSATION PHE- NOMENON IN WALL MADE OF HEMP - LIME COMPOSITE}

\section{Sum mary}

The presence of organic components in building materials, decides on their sensitivity to moisture, and the long-term impact on their biological corrosion, if they are not adequately protected against the weather. Partitions should be designed with attention to the risk of surface and interstitial condensation. The article presents an analysis of the external wall, made of hemp-lime composite with a thickness of $400 \mathrm{~mm}$, plastered on both sides (a thickness of plaster was $20 \mathrm{~mm}$ ). The composite consists of a modified lime binder and hemp shives obtained from the industrial hemp. The parameters of the material needed for analysis (thermal conductivity coefficient and water vapor permeability) was determined experimentally in the own research. In the analytical part of the paper presents the calculation of the internal surface temperature to avoid critical surface humidity and defines the possibility of interstitial condensation in the analyzed wall. For the calculations it was applied the methodology according to PN EN 13788 Standard. Analysis of the walls were made taking Lublin city as location (boundary conditions). The critical month, in which the partition is the most exposed to condensation was January. Due to the good thermal insulation of partition, its construction, the risk of mold growth on the inner wall surface does not occur. The interstitial condensation occurs in the period of December - February. The accumulated condensate is completely evaporated in March. The appropriate thickness of partition made of hemp-lime 
composite, due to its high water vapor permeability and low thermal conductivity is not exposed to long-lasting and devastating impact of water vapor condensation.

Keywords: water vapor permeability, thermal conductivity, organic fillers, lime, external wall

DOI:10.7862/rb.2016.245

Przestano do redakcji: 10.07.2016 r.

Przyjęto do druku: 20.12.2016 r. 